\title{
Public-Private Investment and Macroeconomic Determinants: Evidence from MENA Countries
}

\author{
Nader Alber ${ }^{1} \&$ Vivian Bushra Kheir ${ }^{2}$ \\ ${ }^{1}$ Professor of Finance, Ain Shams University, Cairo, Egypt \\ ${ }^{2}$ Assistant Professor, Pharos Higher Institute for Computer Science and Information Systems, Giza, Egypt \\ Correspondence: Nader Alber, Professor of Finance, Ain Shams University, Cairo, Egypt. Tel: 201-005-668-507. \\ E-mail: naderalberfanous@yahoo.com
}

Received: August 30, 2018

Accepted: October 12, 2018

Online Published: December 2, 2018

doi:10.5539/ijef.v11n1p15

URL: https://doi.org/10.5539/ijef.v11n1p15

\begin{abstract}
This paper attempts to demonstrate the relationship between macroeconomic factors and each of Private Investment in Energy (PIE) and Private Investment in Telecoms (PIT) from 1990 to 2016 in 21 MENA countries (Algeria, Bahrain, Djibouti, Egypt, Iran, Iraq, Israel, Jordan, Kuwait, Lebanon, Libya, Malta, Morocco, Oman, Qatar, Saudi Arabia, Syria, Tunisia, United Arab Emirates, Palestine and Yemen).

Results reveal that both PIE and PIT are Granger caused by GDP, Real Interest Rate, Gross fixed capital formation, private sector, stocks traded are Granger causing PIE. Also, Inflation, Exports of goods and services and Commercial bank branches are Granger causing PIT. All of the ten macroeconomic variables taken up in study are cointegrated with Investment in energy and telecoms with private participation in the long run.

Besides, shocks to all of GDP, gross fixed capital formation, private sector to GDP, general government final consumption expenditure, stocks traded and commercial bank branches (as a proxy of financial inclusion) have a positive and statistically significant effect on the private investment in energy and telecoms.
\end{abstract}

Keywords: financial inclusion, Granger causality test, impulse response analysis, Johansen's cointegration test, macroeconomic factors, private participation investment, unit root, vector auto regression

\section{Introduction}

In the early 1990s the public sector has "over invested" and that public investment competes, rather than fosters, private investment. The state dominates the financial sector and the impact of private sector initiatives is limited by their slow implementation and partial nature (Page, 1998).

Actually, the absence of dynamic private sectors in MENA's economies has been especially felt in the area of investment (World Bank, 1995). Despite efforts to reduce their size, the share of MENA's public sectors in output and employment still exceeds the average for developing and industrialized countries. For MENA's economies, governments influence economic activity in two ways. First, public sector investment in large and typically crowds out investment by private sector. In 1990s public sector investment represented $46 \%$ of total investment. Second, government policies and institutions do not support private investment and are designed to allow governments to influence private sector decisions about resource allocation (Anderson \& Martinez, 1998). However, the decline in public investment rates was not always compensated by a rise in private investment. As a result, capital accumulation rates on a per worker basis stagnated in the past two decades (Nabli \& Keller, 2002).

It was expected that the policy shift should put MENA economies on the path of recovery and sustainable development. But despite this structural reform, MENA economies continues to be confronted with a number of economic problems. Among these problems are low level of savings and investment, high rate of inflation, high level of unemployment and poverty. Hence, the expected role of private sector as an engine of growth never materialized. This study has tried to explore the relationship especially the short-run and long run causal relationship between investment in energy and telecoms with private participation and ten macroeconomic variables.

The remainder of the paper is organized as follows. Section 2 presents some related literature review and section 3 provides a brief overview of direct and indirect channels through which public investment may affect private 
investment. Section 4 describes some econometric techniques, such as ADF and PP Unit root stationarity test, Granger Causality test to check for the short-run causal relation, Johansen's cointegration test to determine the long-run relation, Vector Auto Regression (VAR) and Impulse Response analysis. Section 5 illustrates data description and hypotheses development. Section 5 draws discuss the results with some policy implications of our analysis.

\section{Literature Review}

The literature is fairly settled on the factors that constrained or determine private investment. According to Balassa (1988) in his study of 30 countries indicates the presence of a negative relationship between private investment and public investment. Greene and Villanueva (1991) carries out some empirical studies on 23 countries during 1975-87 and finds that the rate of private investment is positively related to real GDP growth, level of per capita GDP, and the rate of public sector investment, and negatively related to real interest rates, domestic inflation, the debt-service ratio, and the ratio of debt to GDP. The impact of most variables is greatest before the 1982 debt crisis.

Duncan et al. (1999) points out that such a negative relationship might not exist in the case of Pacific Islands, which have no difficulties accessing foreign savings. When the cost of capital is increased by raising the cost of bank credit or by increasing the cost of retained earnings, which is the main source of financing investment, there is a decline in investment. Moreover, certain studies like Greene and Villanueva (1991) and Serven and Solimano (1992) have confirmed the negative relationship between interest rates and investment.

Employing the variability in real exchange rates as an explanatory variable in regression analysis, Jayaraman (1996) in his cross-country study on the macroeconomic environment and private investment in six Pacific Island countries observed a statistically significant negative relationship between the variability in the real exchange rate and private investment. Thomas (1997) in his study of 86 developing countries concludes that while factors including credit, availability and the quality of physical and human infrastructure are important influences, uncertainty in the investment environment is negatively related to private investment in sub- Saharan countries.

Also, a group of studies focuses on the link between total public investment and private investment, using both individual-country based regressions and dynamic panel regressions such as Akkina and Celebi (2002), Apergis (2000), Erenburg and Wohar (1995), Laopodis (2001), Dhumale (2000), Ramírez (2000), and Narayan (2004). For instance, Apergis (2000) uses cointegration techniques and finds that the relationship between public and private investment in Greece is positive during the period 1948-80 but negative during the period 1981-86. In a study of 8 Latin American countries during the period 1980-95, Ramírez (2000) indicates that public investment expenditure has a positive (albeit lagged) effect on private capital formation, suggesting a "crowding in" effect. Besides, Narayan (2004), using a bivariate framework, finds that public and private investment were cointegrated in Fiji during the period 1950-75; in the long run, a $1 \%$ increase in government investment led to an increase in private investment of between $1.1 \% 1.6 \%$.

Many of scholars focus on the link between total public investment and private investment such as Ghura and Goodwin (2000), Miller and Tsoukis (2001), and Everhart and Sumlinski (2001). For instance, Ghura and Goodwin (2000), uses panel regression techniques to address the determinants of private investment in a group of 31 countries in Asia, Latin America, and sub-Saharan Africa. Results show that total public investment has a positive and significant impact on private capital formation in sub-Saharan Africa, while it has the opposite effect in Asia and Latin America. Similar results are obtained by Everhart and Sumlinski (2001), using a broader sample.

Recent studies such as Somma and Rubino (2016) and Saidi and Shahbaz (2018) concern with this area. Somma and Rubino (2016) finds that investment in infrastructure, although historically dominated by public intervention, is experiencing a growing role for public and private partnership. This trend traced a steady increase since the start of privatization and liberalization process that took place in most OECD countries in the 90s and peaked in 2012. Middle East and North African (MENA) countries are hungry for infrastructural investment, but looking at the consolidated global trends in energy investment, it emerges that its performance is particularly poor in attracting private participation. However, the institutional and political endowment in MENA countries appear to be inappropriate to secure the level of infrastructural investment in the energy sector, in particular when dominated by long lead times and irreversibility. In this context, renewable energy sources investment offer a valid alternative, when the necessary pre-conditions are put in place and when the regulatory design is able to offset, at least partially, the higher country risk that investor are likely to face.

Saidi and Shahbaz (2018) investigates the impact of transport energy consumption and transport infrastructure on economic growth for MENA countries. The MENA region is divided into three sub-panels: Gulf Cooperation Council countries (GCC), Non-Gulf Cooperation Council countries (N-GCC) and North African countries, or 
MATE countries. The Generalized Method of Moments is applied to examine the relationship between the variables over the period of 2000-2016. The causal relationship between the variables is investigated by applying the Dumitrescu-Hurlin panel causality test. The empirical results show that a positive and significant association is found between transport infrastructure and economic growth in all regions of MNA countries. Capitalization, which is a supporting variable, also adds to economic growth in GCC, N-GCC and MATE countries. The Dumitrescu-Hurlin panel causality analysis shows that road energy consumption and economic growth have bidirectional causality association in the global, GCC and N-GCC panels, and the energy-led-growth hypothesis is confirmed in the MATE panel.

\section{Public-Private Investment: Transmission Channels}

Public investment and capital can affect private investment through various channels. These channels could be classified into two sets of effects: complementarity and crowding-out effects, and output and relative price effects.

\subsection{Complementarity and Crowding-Out Effects}

The complementarity effect asserts that public capital in may stimulate private physical capital formation because of its impact on private activity. By raising the marginal productivity of private inputs (both labor and capital), it raises the perceived rate of return on, and increases the demand for, physical capital by the private sector. Alternatively, a complementarity effect between public capital and private investment may operate through adjustment costs. Other components of current public spending, related for instance to the enforcement of property rights, can also exert a positive indirect effect on private investment.

Nevertheless, to the extent that public investment displaces or crowds out private investment, its net positive impact on private capital formation can be highly mitigated. Such crowding-out effects tend to occur if the public sector finances the increase in public investment through an increase in distortionary taxes-which may increase incentives for private agents to evade taxation or reduce the expected net rate of return to private capital, and therefore the propensity to invest. A similar effect on private capital formation may occur if the increase in public investment is paid for by borrowing on domestic financial markets (Agénor \& Moreno, 2006).

\subsection{Indirect Output and Relative Price Effects}

Public investment may also affect private capital formation indirectly, through changes in output and relative prices. An increase in public investment will raise aggregate demand and domestic prices (in addition to stimulating output). If the nominal exchange rate does not depreciate fully to offset the increase in domestic prices, the domestic-currency price of imported consumption goods will fall in relative terms (that is, the real exchange rate will appreciate), thereby stimulating demand for these goods and dampening domestic activity. The net effect on output may be positive or negative, depending on the intra-temporal elasticity of substitution between domestic and imported goods (Xavier, Doppelhofer, \& Miller, 2004).

In addition to these effects changes in domestic prices and the real exchange rate induced by an increase in the flow of public investment may affect private investment through both demand- and supply-side effects on output. On the demand side, the increase in domestic prices may lower private sector real wealth and thus expenditure. On the supply side, the real appreciation may lead to a shift in resource allocation toward the non-tradable goods sector, thereby stimulating investment in that sector and depressing capital formation in the tradable goods sector (Nabli et al., 2007).

It is important to note that both the direction and the strength of the various effects described above can vary over time and depend to a very large extent on the environment in which private investors are operating. That is, in the short term, the crowding-out effect may predominate (because the pool of resources available to finance public and private investment is limited), whereas the complementarity effect may prevail in the long term, as a result of strong supply-side effects.

\section{Data Description and Hypotheses Development}

\subsection{Data Description}

The study uses annual data for investment in energy and telecoms with private participation (current US\$) and ten macroeconomic factors: GDP, Real Interest Rate, Gross fixed capital formation, private sector, stocks traded are Granger causing PIE. Also, Inflation, Exports of goods and services and Commercial bank branches and automated teller machines. The data has been collected from the World Bank for the period of 1990 to 2016. Table 1 illustrates how to measure the research variables as follows: 
Table 1. Research variables

\begin{tabular}{lcc}
\hline Variable & Sign & Calculation \\
\hline Investment in Energy with private participation & PIE & (current US\$) \\
Investment in transport with private participation & PIT & (current US\$) \\
Gross Domestic Product & GDP & (current US\$) \\
Gross fixed capital formation, private sector & GFC & (current US\$) \\
General government final consumption expenditure & GGC & Consumer prices (annual \%) \\
Inflation & INF & (current US\$) \\
Real interest rate & RIR & (otal (\% of total labor force) \\
Stocks traded, total value & STV & (current US\$) \\
Unemployment & UNE & (per 100,000 adults) \\
Exports of goods and services & EGS & (per 100,000 adults) \\
Commercial bank branches & CBB & ATM \\
Automated teller machines & & \\
\hline
\end{tabular}

\subsection{Hypotheses Development}

This paper aims at testing the following hypotheses:

H01: There's no significant effect of GDB on PIE and PIT.

H02: There's no significant effect of GFC on PIE and PIT.

H03: There's no significant effect of GGC on PIE and PIT.

H04: There's no significant effect of INF on PIE and PIT.

H05: There's no significant effect of RIR on PIE and PIT.

H06: There's no significant effect of STV on PIE and PIT.

H07: There's no significant effect of UNI on PIE and PIT.

H08: There's no significant effect of EGS on PIE and PIT.

H09: There's no significant effect of CBB on PIE and PIT.

H10: There's no significant effect of ATM on PIE and PIT.

To test the above-mentioned hypotheses, we have conducted the following statistical and econometric techniques:

\subsubsection{Granger Causality Test}

To test for short-term causal relationship between investment in energy and telecoms with private participation and other macroeconomic variables we have used Granger Causality test (Granger, 1969, 1988) which implies that a time series X Granger causes Y. Granger Causality test includes running the following two equations to check for the direction of causality among stock market indicators and real macroeconomic factors.

$$
\begin{aligned}
& X t=\alpha_{1}+\sum_{k=1}^{m} \beta 1 k X t-k+\sum_{k=1}^{m} \gamma 1 k+Y t-k+e_{1 t} \\
& Y t=\alpha_{2}+\sum_{k=1}^{m} \beta 2 k Y t-k+\sum_{k=1}^{m} \gamma 2 k+X t-k+e_{2 t}
\end{aligned}
$$

Where, $\mathrm{Yt}$ and $\mathrm{Xt}=$ the variables to be tested;

$\mathrm{e} 1 \mathrm{t}$ and $\mathrm{e} 2 \mathrm{t}=$ white noise error terms,

$\mathrm{t}=$ time period,

$\mathrm{k}=$ number of lags and $\mathrm{m}=$ maximum number of lagged observations included in the model.

The null hypothesis is $\gamma 1=\gamma 2=0$ for all k's versus $\gamma 1 \neq \gamma 2 \neq 0$ for at least some k's. If the coefficients $\gamma 1$ are significantly significant but $\gamma 2$ are not, then Y Granger causes X. Vice versa for X Granger causing .

\subsubsection{Johansen Cointegration Test}

It is used to check the presence of long-run equilibrium relationship between the variables taking non-stationary series. This test uses the maximum likelihood procedure to check for cointegrating vectors in non-stationary time series as a VAR. Consider a VAR of order $\mathrm{k}$

$$
Y t=A_{1} Y t_{1}+A_{2} Y t_{2}+\ldots \ldots \ldots+A_{\mathrm{K}} Y_{\mathrm{TK}}+B X_{\mathrm{T}}+\varepsilon t
$$

Where, 
$\mathrm{Y}_{\mathrm{t}}=\mathrm{a}$ k-vector of non-stationary I (1) variables,

$\mathrm{X}_{\mathrm{t}}=$ the vector of deterministic variables,

$\mathrm{K}=$ the number of lags and

$\varepsilon_{\mathrm{t}}=$ vector of innovations or error terms.

The VAR can be re-written as:

$$
\Delta Y t=\alpha_{2}+\pi Y t-1+\sum_{i=1}^{k-1} \tau \Delta Y t-i+\beta X t+\varepsilon_{t}
$$

where,

$$
\begin{aligned}
\pi & =\left(\sum_{i=1}^{k} A i\right)-1 \\
\tau & =-\sum_{j=i+1}^{k-1} A j
\end{aligned}
$$

Here, $\mathrm{Yt}$ is a vector of non-stationary variables. The information available from the coefficient matrix between the levels of the series $\Pi$ can be expressed as $\Pi=\mathrm{a} \beta^{\prime}$ where a matrix contain adjustment coefficients and the $\mathrm{b}$ matrix contains the cointegrating vectors. Vector Auto Regression (VAR) Short-run equilibrium relationship is also tested using VAR model. The reduced form of VAR is given by Equation (7) as follows:

$$
y t=c+\sum_{i=0}^{p} A i y t-1+e_{t}
$$

\subsubsection{Impulse Response Function}

Impulse Response Function has been used to gauge the response of investment in energy and telecoms with private participation to shocks generated in the real economy and stock market with the help of graphs. Here, we have used Cholesky decomposition method which is one of the popular methods for this purpose.

\section{Results of Empirical Study}

This section analyses the relationship between investment in energy and telecoms with private participation and all macroeconomic variables taken up in the study using Covariance Correlation Analysis in table 4 and the Granger causality tests in Table 5, Johansen co-integration in Table 6, and the impulse response functions in Figure 1 in the Appendix.

Prior to carrying out the analysis the lag length selection criteria is used to select the optimal lag length. The results presented in Table 2 shows that the optimal lag length is three lags using the Likelihood Ratio (LR) test, the Final Prediction Error (FPE), and the Akaike Information Criterion (AIC). The Schwarz criterion indicates four lags whilst the Hannan-Quinn criterion (HQ) selects six lags. Consequently, eight lags are considered in making the analysis.

Table 2. VAR lag order selection criteria

\begin{tabular}{ccccccc}
\hline Lag & LogL & LR & FPE & AIC & SC & HQ \\
\hline 0 & -12175.17 & NA & $1.33 e+08$ & 52.75831 & 52.86573 & 52.80060 \\
1 & -11121.01 & 2049.004 & 2581438. & 48.81820 & 50.21463 & 49.36799 \\
2 & -10575.35 & 1032.252 & 454154.3 & 47.07945 & $49.76488^{*}$ & 48.13672 \\
3 & -10262.60 & $575.4160^{*}$ & $219367.6^{*}$ & $46.34890^{*}$ & 50.32334 & $47.91367^{*}$ \\
\hline
\end{tabular}

Source: Authors' computation using Eviews 8.

* indicates lag order selected by the criterion.

LR: sequential modified LR test statistic (each test at $5 \%$ level).

FPE: Final prediction error.

AIC: Akaike information criterion.

SC: Schwarz information criterion.

HQ: Hannan-Quinn information riterion.

Table 3 shows the results of ADF and PP unit root tests. Both ADF and PP unit root tests suggest that all the series are stationary at first difference. 
Table 3. Panel root test

\begin{tabular}{|c|c|c|c|c|c|c|c|c|c|c|}
\hline Variables & $\begin{array}{c}\text { PP-Fisher } \\
\text { Chi-square (Ho: } \\
\text { unit root) }\end{array}$ & $\begin{array}{l}\text { PP-Fisher } \\
\text { Chi-square } \\
\text { (P-value) }\end{array}$ & $\begin{array}{c}\text { ADF-Fisher } \\
\text { Chi-square } \\
\text { (Ho: unit root) }\end{array}$ & $\begin{array}{c}\text { ADF-Fisher } \\
\text { Chi-square } \\
\text { (P-value) }\end{array}$ & $\begin{array}{c}\text { Im, Pesaran } \\
\text { and Shin } \\
\text { W-stat }\end{array}$ & $\begin{array}{c}\text { Im, Pesaran } \\
\text { and Shin } \\
\text { W(P-value })\end{array}$ & $\begin{array}{c}\text { Breitung } \\
\text { t-stat }\end{array}$ & $\begin{array}{l}\text { Breitung } \\
\text { (P-value) }\end{array}$ & $\begin{array}{l}\text { Levin, Lin } \\
\text { \& Chu t* } \\
\text {-stat }\end{array}$ & $\begin{array}{l}\text { Levin, Lin } \\
\& \text { Chu }^{*} \\
\text { (P-value) }\end{array}$ \\
\hline PIE & 2160.44 & 0 & 144.118 & 0 & -12.5967 & 0 & -6.8 & 0 & -1.18475 & 0.1181 \\
\hline PIT & 2897.3 & 0 & 307.089 & 0 & -22.8614 & 0 & -4.23917 & 0 & -17.0033 & 0 \\
\hline GDP & 3488.98 & 0 & 378.395 & 0 & -20.9638 & 0 & -2.20326 & 0.0138 & -17.4304 & 0 \\
\hline GFCF & 2432.95 & 0 & 209.658 & 0 & -15.7282 & 0 & -7.55257 & 0 & -11.4581 & 0 \\
\hline GGFC & 3388.83 & 0 & 366.660 & 0 & -19.9379 & 0 & -3.99405 & 0 & -20.2038 & 0 \\
\hline INF & 5041.7 & 0 & 500.080 & 0 & -21.8845 & 0 & -4.79214 & 0 & -10.7751 & 0 \\
\hline RIR & 3359.6 & 0 & 195.029 & 0 & -12.9439 & 0 & -0.12537 & 0.4501 & 8.86578 & 1.0000 \\
\hline STV & 3731.16 & 0 & 439.220 & 0 & -24.607 & 0 & -10.0956 & 0 & -18.8351 & 0 \\
\hline UNE & 4987.45 & 0 & 2339.32 & 0 & -274.498 & 0 & -2.26031 & 0.0119 & -757.81 & 0 \\
\hline EGS & 3069.44 & 0 & 316.052 & 0 & -19.4031 & 0 & -2.63002 & 0.0043 & 9.66552 & 0 \\
\hline $\mathrm{CBB}$ & 4795.54 & 0 & 478.646 & 0 & -28.6336 & 0 & -15.9073 & 0 & -30.0744 & 0 \\
\hline ATM & 3733.27 & 0 & 395.846 & 0 & -23.2999 & 0 & -6.42891 & 0 & -24.7784 & 0 \\
\hline
\end{tabular}

Source: Authors' computation using Eviews 8.

Covariance Correlation Analysis in Table 4 shows that all macroeconomic variables taken up in the study has positive and significant (except for Stocks traded, total value (\% of GDP) and Automated teller machines) correlation with both PIE and PIT. Also, GDP has not a significant correlation with PIE and Gross fixed capital formation, private sector (\% of GDP) has not a and significant correlation with PIT.

Table 4. Covariance correlation analysis

\begin{tabular}{|c|c|c|c|}
\hline \multicolumn{2}{|c|}{ Item } & \multirow{2}{*}{$\begin{array}{c}\text { D(LNPIE ) } \\
5.498984\end{array}$} & \multirow{2}{*}{$\begin{array}{c}\text { D(LNPIT ) } \\
3.782390\end{array}$} \\
\hline & Coefficient & & \\
\hline D(LNGDP) & Standard Error & 0.114368 & 0.050319 \\
\hline & Probability & 0.0064 & 0.2316 \\
\hline \multirow{3}{*}{$\mathrm{D}(\mathrm{LNGFCF})$} & Coefficient & 0.288908 & 2.003067 \\
\hline & Standard Error & 0.041041 & 0.182009 \\
\hline & Probability & 0.3293 & 0.0000 \\
\hline \multirow{3}{*}{ D(LNGGFC) } & Coefficient & 1.436987 & 5.796427 \\
\hline & Standard Error & 0.034937 & 0.090144 \\
\hline & Probability & 0.4064 & 0.0319 \\
\hline \multirow{3}{*}{ D(LNINF ) } & Coefficient & -0.054425 & 1.618109 \\
\hline & Standard Error & -0.008172 & 0.155413 \\
\hline & Probability & 0.8460 & 0.0002 \\
\hline \multirow{3}{*}{ D(LNRIR) } & Coefficient & $0.603528 *$ & 1.610448 \\
\hline & Standard Error & 0.080415 & 0.137256 \\
\hline & Probability & 0.0557 & 0.0011 \\
\hline \multirow{3}{*}{ D(LNSTV) } & Coefficient & 4.047583 & 3.349200 \\
\hline & Standard Error & 0.067169 & 0.035552 \\
\hline & Probability & 0.1101 & 0.3981 \\
\hline \multirow{3}{*}{ D(LNUNE ) } & Coefficient & $0.404007 *$ & 1.907853 \\
\hline & Standard Error & 0.072137 & 0.217898 \\
\hline & Probability & 0.0861 & 0.0000 \\
\hline \multirow{3}{*}{ D(LNEGS ) } & Coefficient & $4.778704 *$ & $7.296666^{*}$ \\
\hline & Standard Error & 0.073004 & 0.071302 \\
\hline & Probability & 0.0824 & 0.0898 \\
\hline \multirow{3}{*}{ D(LNCBB ) } & Coefficient & 0.775586 & 1.587937 \\
\hline & Standard Error & 0.108800 & 0.142486 \\
\hline & Probability & 0.0095 & 0.0007 \\
\hline \multirow{3}{*}{ D(LNATM ) } & Coefficient & 0.211570 & 0.296176 \\
\hline & Standard Error & 0.023941 & 0.021438 \\
\hline & Probability & 0.5694 & 0.6105 \\
\hline
\end{tabular}

Note. $* 10$ per cent as level of significance. 


\subsection{Granger Causality Test}

Akaike Information Criterion (AIC) and Schwarz Information Criterion (SC) are employed to determine the optimal lag length before we used the Granger Causality test. The optimal lag length was two. So, the entire analysis is performed at two as well as six lag lengths. As per results reported in Table 3.

Both PIE and PIT are Granger caused by GDP at six and two lag respectively, Real Interest Rate at two lag. Further, Gross fixed capital formation, private sector, Stocks traded, total value are Granger causing PIE at two lag. Also, Inflation at six lag, Exports of goods and services and Commercial bank branches (per 100,000 adults) at two lag are Granger causing PIT. Under two and six lag GDP is Granger caused by PIT .

Table 5. Pairwise Granger causality tests

\begin{tabular}{|c|c|c|c|c|c|}
\hline \multicolumn{6}{|c|}{ Lag: 2} \\
\hline Null Hypothesis: & Obs & F-Statistic & Prob. & F-Statistic & Prob. \\
\hline D(LNGDP) does not Granger Cause D(LNPIE) & 483 & 0.55039 & 0.5771 & 2.87148 & 0.0095 \\
\hline D(LNPIE) does not Granger Cause D(LNGDP) & & 0.00016 & 0.9998 & 0.04948 & 0.04948 \\
\hline D(LNGFCF) does not Granger Cause D(LNPIE) & 483 & 2.57749 & 0.0770 & 1.13550 & 0.3409 \\
\hline (D(LNPIE) does not Granger Cause D(LNGFCF) & & 0.24922 & 0.7795 & 1.09705 & 1.09705 \\
\hline D(LNGGFC) does not Granger Cause D(LNPIE) & 483 & 0.64538 & 0.5249 & 0.90529 & 0.4910 \\
\hline D(LNPIE) does not Granger Cause D(LNGGFC) & & 0.34129 & 0.7110 & 0.36634 & 0.36634 \\
\hline D(LNINF) does not Granger Cause D(LNPIE) & 483 & 0.25798 & 0.7727 & 0.61627 & 0.7173 \\
\hline D(LNPIE) does not Granger Cause D(LNINF) & & 0.03464 & 0.9660 & 0.52522 & 0.52522 \\
\hline D(LNRIR) does not Granger Cause D(LNPIE) & 483 & 2.95068 & 0.0533 & 1.94795 & 0.0722 \\
\hline D(LNPIE) does not Granger Cause D(LNRIR) & & 0.29089 & 0.7477 & 0.90562 & 0.90562 \\
\hline D(LNSTV) does not Granger Cause D(LNPIE) & 483 & 2.65832 & $0.0711 *$ & 1.74970 & 0.1084 \\
\hline D(LNPIE) does not Granger Cause D(LNSTV) & & 0.04519 & 0.9558 & 1.18791 & 1.18791 \\
\hline D(LNUNE) does not Granger Cause D(LNPIE) & 483 & 0.13517 & 0.8736 & 0.78056 & 0.5856 \\
\hline D(LNPIE)) does not Granger Cause D(LNUNE) & & 0.22022 & 0.8024 & 0.09834 & 0.09834 \\
\hline D(LNEGS) does not Granger Cause D(LNPIE) & 483 & 1.68558 & 0.1864 & 1.06386 & 0.3837 \\
\hline D(LNPIE) does not Granger Cause D(LNEGS) & & 0.06611 & 0.9360 & 0.10021 & 0.10021 \\
\hline $\mathrm{D}(\mathrm{LNCBB})$ does not Granger Cause $\mathrm{D}$ (LNPIE) & 483 & 0.67798 & 0.5081 & 0.73900 & 0.6185 \\
\hline D(LNPIE) does not Granger Cause D(LNCBB) & & 0.84828 & 0.4288 & 0.34334 & 0.34334 \\
\hline D(LNATM) does not Granger Cause D(LNPIE) & 483 & 0.07819 & 0.9248 & 0.66956 & 0.6743 \\
\hline D(LNPIE) does not Granger Cause D(LNATM) & & 0.13703 & 0.8720 & 0.65700 & 0.65700 \\
\hline D(LNGDP) does not Granger Cause D(LNPIT) & 483 & 3.84427 & 0.0221 & 0.55205 & 0.7684 \\
\hline $\mathrm{D}$ (LNPIT) does not Granger Cause D(LNGDP) & & 1.73587 & 0.1774 & 1.27603 & 1.27603 \\
\hline $\mathrm{D}(\mathrm{LNGFCF})$ does not Granger Cause D(LNPIT) & 483 & 0.37755 & 0.6857 & 1.27638 & 0.2671 \\
\hline D(LNPIT) does not Granger Cause D(LNGFCF) & & 0.81061 & 0.4452 & 0.93939 & 0.93939 \\
\hline D(LNGGFC) does not Granger Cause D(LNPIT) & 483 & 0.46267 & 0.6299 & 0.37889 & 0.8924 \\
\hline D(LNPIT) does not Granger Cause D(LNGGFC) & & 0.59416 & 0.5524 & 0.58799 & 0.58799 \\
\hline $\mathrm{D}$ (LNINF) does not Granger Cause D(LNPIT) & 483 & 1.08760 & 0.3379 & 2.29823 & 0.0342 \\
\hline D(LNPIT) does not Granger Cause D(LNINF) & & 0.47764 & 0.6205 & 0.28704 & 0.28704 \\
\hline D(LNRIR) does not Granger Cause D(LNPIT) & 483 & 0.03466 & 0.9659 & 0.73906 & 0.6184 \\
\hline D(LNPIT) does not Granger Cause D(LNRIR) & & 3.32391 & 0.0368 & 0.79413 & 0.79413 \\
\hline $\mathrm{D}$ (LNST) does not Granger Cause D(LNPIT) & 483 & 0.17163 & 0.8423 & 1.00657 & 0.4205 \\
\hline D(LNPIT) does not Granger Cause D(LNSTV) & & 1.01044 & 0.3648 & 0.89449 & 0.89449 \\
\hline $\mathrm{D}$ (LNUNE) does not Granger Cause D(LNPIT) & 483 & 0.70765 & 0.4933 & 0.61077 & 0.7217 \\
\hline D(LNPIT) does not Granger Cause D(LNUNE) & & 0.54526 & 0.5801 & 0.31767 & 0.31767 \\
\hline D(LNEGS) does not Granger Cause D(LNPIT) & 483 & 4.78488 & 0.0088 & 1.13685 & 0.3401 \\
\hline D(LNPIT) does not Granger Cause D(LNEGS) & & 0.17817 & 0.8369 & 0.23990 & 0.23990 \\
\hline $\mathrm{D}(\mathrm{LNCBB})$ does not Granger Cause $\mathrm{D}(\mathrm{D}$ (LNPIT) & 483 & 4.31264 & 0.0139 & 1.93395 & $0.0743 *$ \\
\hline D(LNPIT) does not Granger Cause D(LNCBB $)$ ) & & 1.36483 & 0.2564 & 1.00438 & 1.00438 \\
\hline D(LNATM) does not Granger Cause D(LNPIT) & 483 & 0.83014 & 0.4366 & 0.73717 & 0.6200 \\
\hline D(LNPIT) does not Granger Cause D(LNATM) & & 0.38604 & 0.6800 & 0.16475 & 0.16475 \\
\hline
\end{tabular}

Note. * 10 per cent as level of significance. 


\subsection{Johansen's Cointegration Test}

Johansen cointegration test is used to study the long-term causal relation between Investment in energy and telecoms with private participation and macroeconomic variables. As per the results shown in Table 5, all of the ten macroeconomic variables taken up in study are cointegrated with Investment in energy and telecoms with private participation in the long run, namely, Gross fixed capital formation, private sector (\% of GDP), General government final consumption expenditure (current US\$), Inflation (consumer prices, annual \%), Real Interest rate (\%), Stocks traded, total value (\% of GDP), Unemployment, total (\% of total labor force), Exports of goods and services (constant 2010 US\$), Commercial bank branches (per 100,000 adults), Automated teller machines (ATMs) (per 100,000 adults).

Table 6. Johansen fisher panel cointegration test

\begin{tabular}{|c|c|c|c|c|c|}
\hline D(LNPIE) & & & & & \\
\hline & Hypothesized No. of CE(s) & Fisher Stat.* (from trace test) & Prob. & Fisher Stat.* (from max-eigen test) & Prob. \\
\hline \multirow{2}{*}{ D(LNGDP) } & None & 174.6 & 0.0000 & 210.5 & 0.0000 \\
\hline & At most 1 & 137.3 & 0.0000 & 137.3 & 0.0000 \\
\hline \multirow{2}{*}{$\mathrm{D}$ (LNGFCF) } & None & 143.3 & 0.0000 & 154.5 & 0.0000 \\
\hline & At most 1 & 71.00 & 0.0000 & 71.00 & 0.0000 \\
\hline \multirow{2}{*}{$\mathrm{D}(\mathrm{LNGGFC})$} & None & 184.9 & 0.0000 & 183.7 & 0.0000 \\
\hline & At most 1 & 344.1 & 0.0000 & 344.1 & 0.0000 \\
\hline \multirow{2}{*}{$\mathrm{D}(\mathrm{LNINF})$} & None & 218.0 & 0.0000 & 235.7 & 0.0000 \\
\hline & At most 1 & 92.74 & 0.0000 & 92.74 & 0.0000 \\
\hline \multirow{2}{*}{$\mathrm{D}(\mathrm{LNRIR})$} & None & 90.54 & 0.0000 & 97.87 & 0.0000 \\
\hline & At most 1 & 117.4 & 0.0000 & 117.4 & 0.0000 \\
\hline \multirow{2}{*}{ D(LNSTV) } & None & 140.7 & 0.0000 & 151.0 & 0.0000 \\
\hline & At most 1 & 103.3 & 0.0000 & 103.3 & 0.0000 \\
\hline \multirow{2}{*}{ D(LNUNE) } & None & 203.0 & 0.0000 & 227.0 & 0.0000 \\
\hline & At most 1 & 377.7 & 0.0000 & 377.7 & 0.0000 \\
\hline \multirow{2}{*}{ D(LNEGS) } & None & 127.1 & 0.0000 & 159.6 & 0.0000 \\
\hline & At most 1 & 336.5 & 0.0000 & 336.5 & 0.0000 \\
\hline \multirow{2}{*}{$\mathrm{D}(\mathrm{LNCBB})$} & None & 137.4 & 0.0000 & 140.2 & 0.0000 \\
\hline & At most 1 & 168.2 & 0.0000 & 168.2 & 0.0000 \\
\hline \multirow{2}{*}{ D(LNATM) } & None & 92.10 & 0.0000 & 92.10 & 0.0000 \\
\hline & At most 1 & 125.2 & 0.0000 & 125.2 & 0.0000 \\
\hline \multicolumn{6}{|l|}{ D(LNPIT) } \\
\hline & Hypothesized No. of CE(s) & Fisher Stat.* (from trace test) & Prob. & Fisher Stat.* (from max-eigen test) & Prob. \\
\hline \multirow{2}{*}{ D(LNGDP) } & None & 193.1 & 0.0000 & 198.7 & 0.0000 \\
\hline & At most 1 & 40.76 & 0.0016 & 40.76 & 0.0016 \\
\hline \multirow{2}{*}{$\mathrm{D}$ (LNGFCF) } & None & 176.4 & 0.0000 & 192.6 & 0.0000 \\
\hline & At most 1 & 313.4 & 0.0000 & 313.4 & 0.0000 \\
\hline \multirow{2}{*}{$\mathrm{D}$ (LNGGFC) } & None & 200.5 & 0.0000 & 245.3 & 0.0000 \\
\hline & At most 1 & 230.3 & 0.0000 & 230.3 & 0.0000 \\
\hline \multirow{2}{*}{ D(LNINF) } & None & 190.9 & 0.0000 & 210.7 & 0.0000 \\
\hline & At most 1 & 82.52 & 0.0000 & 82.52 & 0.0000 \\
\hline \multirow{2}{*}{ D(LNRIR) } & None & 153.3 & 0.0000 & 176.7 & 0.0000 \\
\hline & At most 1 & 320.8 & 0.0000 & 320.8 & 0.0000 \\
\hline \multirow{2}{*}{ D(LNSTV) } & None & 161.5 & 0.0000 & 174.3 & 0.0000 \\
\hline & At most 1 & 221.9 & 0.0000 & 221.9 & 0.0000 \\
\hline \multirow{2}{*}{ D(LNUNE) } & None & 276.5 & 0.0000 & 301.4 & 0.0000 \\
\hline & At most 1 & 89.43 & 0.0000 & 89.43 & 0.0000 \\
\hline \multirow{2}{*}{ D(LNEGS) } & None & 168.0 & 0.0000 & 172.5 & 0.0000 \\
\hline & At most 1 & 74.58 & 0.0000 & 74.58 & 0.0000 \\
\hline \multirow{2}{*}{$\mathrm{D}(\mathrm{LNCBB})$} & None & 164.5 & 0.0000 & 165.9 & 0.0000 \\
\hline & At most 1 & 181.7 & 0.0000 & 181.7 & 0.0000 \\
\hline \multirow{2}{*}{ D(LNATM) } & None & 125.8 & 0.0000 & 124.7 & 0.0000 \\
\hline & At most 1 & 50.50 & 0.0000 & 50.50 & 0.0000 \\
\hline
\end{tabular}

\footnotetext{
* Probabilities are computed using asymptotic Chi-square distribution.
} 


\subsection{Vector Auto Regression (VAR) Test}

The result of VAR for both monthly and quarterly time series data indicates PIE and PIT to be an autoregressive function. It is apparent from the test that investment in energy and telecoms with private participation is caused by its own lagged values rather than the lagged or past values of macroeconomic variables. Detailed results can be obtained from the authors.

\subsection{Impulse Response Function}

Function Impulse Response function is used to examine the response of PIE and PIT to shocks generated in the real economy and the stock market. Figure 1 indicates that the shock to GDP has a positive and statistically significant effect on the private investment in energy beginning in period 4 and lasting for 1 periods. Also, shock to all of Gross fixed capital formation, private sector (\% of GDP), General government final consumption expenditure, Stocks traded, Commercial bank branches and Automated teller machines have a positive and statistically significant effect on the private investment in energy lasting for between 2 periods or 3 periods.

While shock to all of Inflation, Real Interest rate, and Exports of goods and services, have a negative and statistically significant effect on the private investment in energy lasting for between 2 periods or 3 periods. Figure 1 indicates that the shock to all of Gross fixed capital formation, private sector (\% of GDP), General government final consumption expenditure, Commercial bank branches and have a positive and statistically significant effect on the private investment in telecoms lasting for 2 periods. While shock to all of Stocks traded, Unemployment and Automated teller machines have a negative and statistically significant effect on the private investment in telecoms lasting for between 2 periods or 3 periods.

Moreover, Impulse response analysis does not make sense if correlations between the VAR residuals are high. The analysis will be valid if shocks are serially and contemporaneously uncorrelated. To test the robustness of the results the correlation matrix of the reduced-form VAR residuals based on the ordering of variables, which were entered into the VAR. is obtained.

\section{Summary and Conclusion}

This paper attempts to demonstrate the relationship between macroeconomic factors and each of Private Investment in Energy (PIE) and Private Investment in Telecoms (PIT) from 1990 to 2016 in 21 MENA countries (Algeria, Bahrain, Djibouti, Egypt, Iran, Iraq, Israel, Jordan, Kuwait, Lebanon, Libya, Malta, Morocco, Oman, Qatar, Saudi Arabia, Syria, Tunisia, United Arab Emirates, Palestine and Yemen).

Apart from using the standard techniques, such as ADF and PP Unit root stationarity test and Granger Causality test, we have also applied advanced econometric techniques such as Johansen's cointegration test, Vector Auto Regression (VAR) and Impulse Response analysis to check for long-run and short-run dynamic relationship.

Results reveal that both PIE and PIT are Granger caused by GDP, Real Interest Rate, Gross fixed capital formation, private sector, stocks traded are Granger causing PIE. Also, Inflation, Exports of goods and services and Commercial bank branches are Granger causing PIT. All of the ten macroeconomic variables taken up in study are cointegrated with Investment in energy and telecoms with private participation in the long run.

Besides, shocks to all of GDP, gross fixed capital formation, private sector to GDP, general government final consumption expenditure, stocks traded and commercial bank branches (as a proxy of financial inclusion) have a positive and statistically significant effect on the private investment in energy and telecoms.

These research findings have important implications for policy makers and private investors. Policy makers are required to push reform agenda in domestic market so as to attract more investment in energy and telecoms with private participation in MENA economies. The policy makers should make stable and transparent policies to provide safeguard to the foreign investors and gain their confidence.

The unstable policies owing to its frequently changing characteristics weaken the confidence of the investors in the rules and regulations governing the respective sectors of the country. However, lack of transparency leads to unnecessary delays in the approval and the execution of the projects. The presence of positive relationship between investment in energy and telecoms with private participation and profitability indicates a higher investor's confidence in domestic market which can act as a stimulus in attracting investment in energy and telecoms with private participation.

\section{References}

Agénor, P., \& Moreno, B. (2006). Public Infrastructure and Growth: New Channels and Policy Implications. Working Paper; No. 4064. World Bank. Washington. DC. https://doi.org/10.1596/1813-9450-4064 
Anderson, R., \& Martinez, A. (1998). Supporting Private Sector Development in the Middle East and North Africa. In N. Shafik (Ed.), Prospects for Middle Eastern and North African Economies: From Boom to Bust and Back? New York: St. Martin's Press. https://doi.org/10.1007/978-1-349-26137-6_7

Apergis, N. (2000). Public and Private Investments in Greece: Complementary or Substitute 'Goods'? Bulletin of Economic Research, 52(3), 225-234. https://doi.org/10.1111/1467-8586.00106

Balassa, B. (1988). The Lessons of East Asian Development: An Overview. Economic Development and Cultural Change,36(3), 273-290. https://doi.org/10.1086/edcc.36.s3.1566546

Dhumale, R. (2000). Public Investment in the Middle East and North Africa: Towards Fiscal Efficiency. Development Policy Review, 18, 307-324. https://doi.org/10.1111/1467-7679.00113

Duncan, R., Cuthbertson, S., \& Bosworth, M. (1999). Pursuing. Economic Reform in the Pacific. Pacific Studies Series No. 18. Asian Development Bank. Manila.

Erenburg, S. J., \& Wohar M. E. (1995) Public and private investment: Are there causal linkages? Journal of Macroeconomics, 17(1), 1-30. https://doi.org/10.1016/0164-0704(95)80001-8

Everhart, S., \& Sumlinski, A. (2001). Trends in Private Investment in Developing Countries: Statistics for 1970-2000 and the Impact on Private Investment of Corruption and the Quality of Public Investment. IFC Discussion Paper; No. 44. Washington, DC.

Ghura, D., \& Barry, G. (2000). Determinants of Private Investment: A Cross-Regional Empirical Investigation. Applied Economics, 32(14), 1819-29. https://doi.org/10.1080/000368400425044

Greene, J., \& Villanueva, D. (1991). Private Investment in Developing Countries: An Empirical Analysis. IMF Staff Papers, 38, 33-58. https://doi.org/10.2307/3867034

Jayaraman, T. K. (1996). Private Investment and Macroeconomic Environment in the South Pacific Island Countries: A Cross-Country Analysis. Occasional Paper No.14. Asian Development Bank, Manila

Keller, J., \& Nabli, M. (2002). The Macroeconomics of Labor Market Outcomes in MENA over the 1990s: How Growth Has Failed to Keep Pace with a Burgeoning Labor Market. Working Paper No. 71. The World Bank.

Laopodis, N. (2001). Effects of Government Spending on Private Investment. Applied Economics, 33(12). https://doi.org/10.1080/00036840010011934

Miller, N., \& Tsoukis, Ch. (2001). On the Optimality of Public Capital for Long-run Economic Growth: Evidence from Panel Data. Applied Economics, 33(9), 1117-1129. https://doi.org/10.1080/00036840010003258

Nabli, M. et al. (2007). Breaking the Barriers to Higher Economic Growth: Better Governance and Deeper Reforms in the Middle East and North Africa. Working Paper, The World Bank.

Narayan, S., \& Narayan, P. (2004). Determinants of Demand for Fiji's Exports: An Empirical Investigation. The Developing Economy, 42, 95-112. https://doi.org/10.1111/j.1746-1049.2004.tb01017.x

Page, J. (1998). From Boom to Bust-And Back? The Crisis of Economic Growth in the Middle East and North Africa. In N. Shafik (Ed.), Prospects for Middle Eastern and North African Economies: From Boom to Bust and Back? New York: St. Martin's Press. https://doi.org/10.1007/978-1-349-26137-6_5

Ramirez, M. (2000). Foreign Direct Investment in Mexico: A Cointegration Analysis. Journal of Development Studies, 37(1), 138-162. https://doi.org/10.1080/713600062

Saidi, S., Shahbaz, M., \& Akhtar, P. (2018). The long-run relationships between transport energy consumption, transport infrastructure, and economic growth in MENA countries. Transp. Res. Part A Policy Pract, 111, 78-95. https://doi.org/10.1016/j.tra.2018.03.013

Serven, L., \& Solimano, A. (1992). Private Investment and Macroeconomic Adjustment: A Survey. The World Bank Research Observer, 7(1), 95-114. https://doi.org/10.1093/wbro/7.1.95

Somma, E., \& Rubino, A. (2016). Public-Private Participation in Energy Infrastructure in Middle East and North African Countries: The Role of Institutions for Renewable Energy Sources Diffusion. International Journal of Energy Economics and Policy, 6(3), 621-629.

Thomas, R. (1997). Modern Econometrics: An Introduction. Sydney: Addison Wesley.

World Bank. (1995). Claiming the Future: Choosing Prosperity in the Middle East and North Africa. 
Washington DC.

World Bank. (2003). Trade, Investment and Development in the Middle East and North Africa. Washington DC.

Xavier, S., Doppelhofer, G., \& Miller, R. (2004). Determinants of Long-Term Growth: A Bayesian Averaging of Classical Estimates (BACE) Approach. American Economic Review, 94(4), 813-35. https://doi.org/10.1257/0002828042002570

\section{Appendix}

Response of $D($ LNPIE) to Cholesky One S.D. D(LNPIE) Innovation
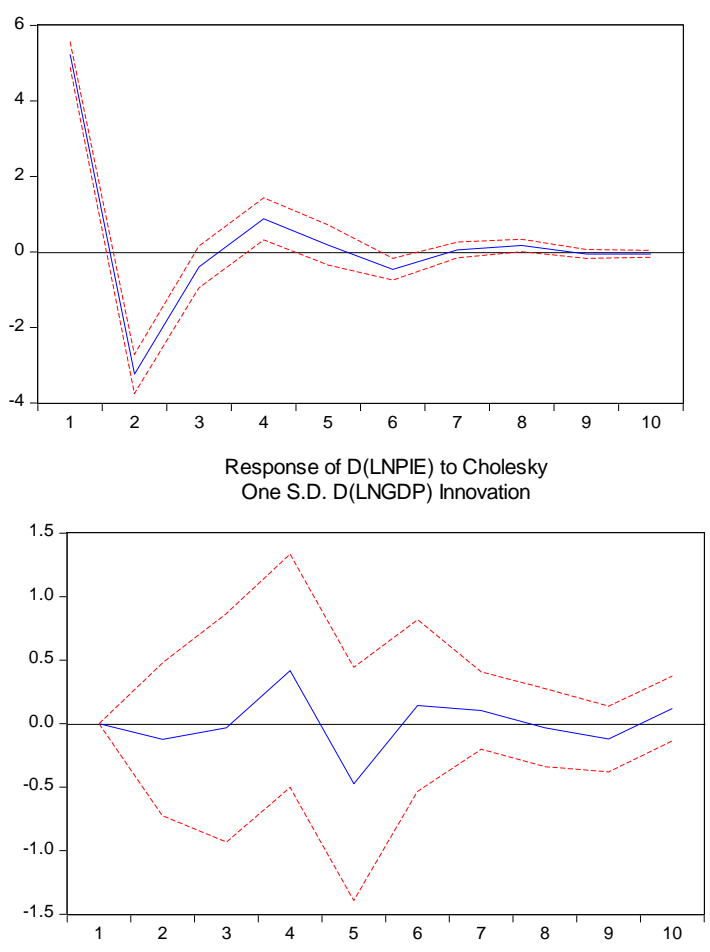

Response of D(LNPIE) to Cholesky

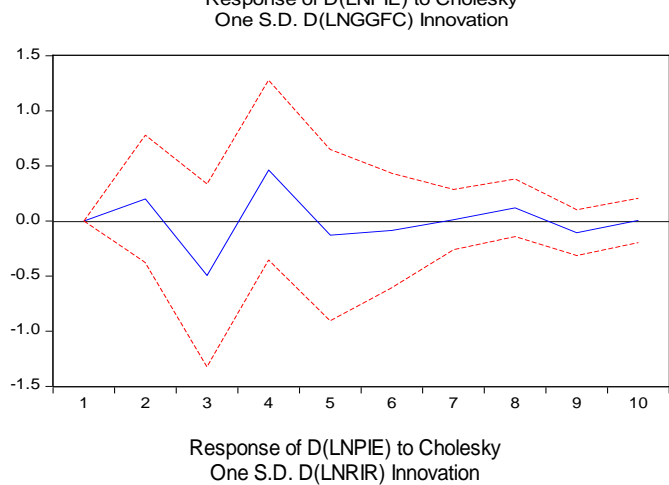

Response of D(LNPIE) to Cholesky

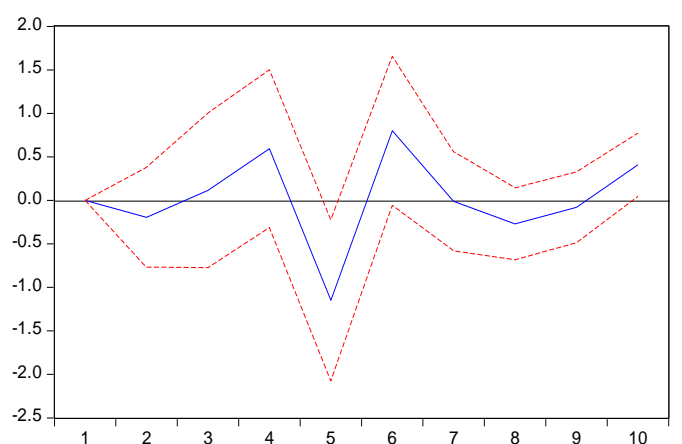

Response of D(LNPIT) to Cholesky One S.D. D(LNPIT) Innovation

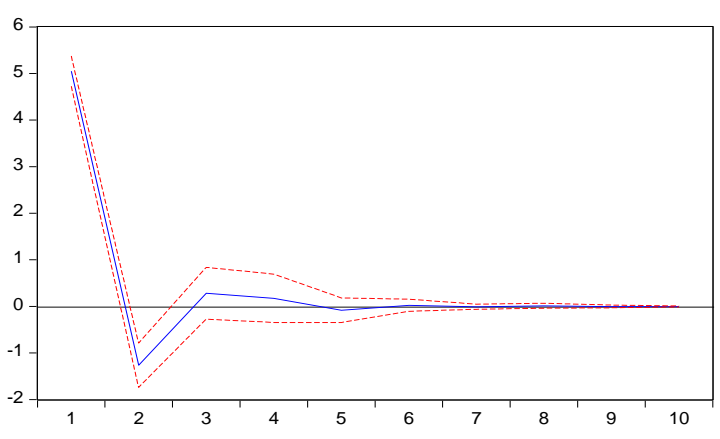

Response of D(LNPIE) to Cholesky
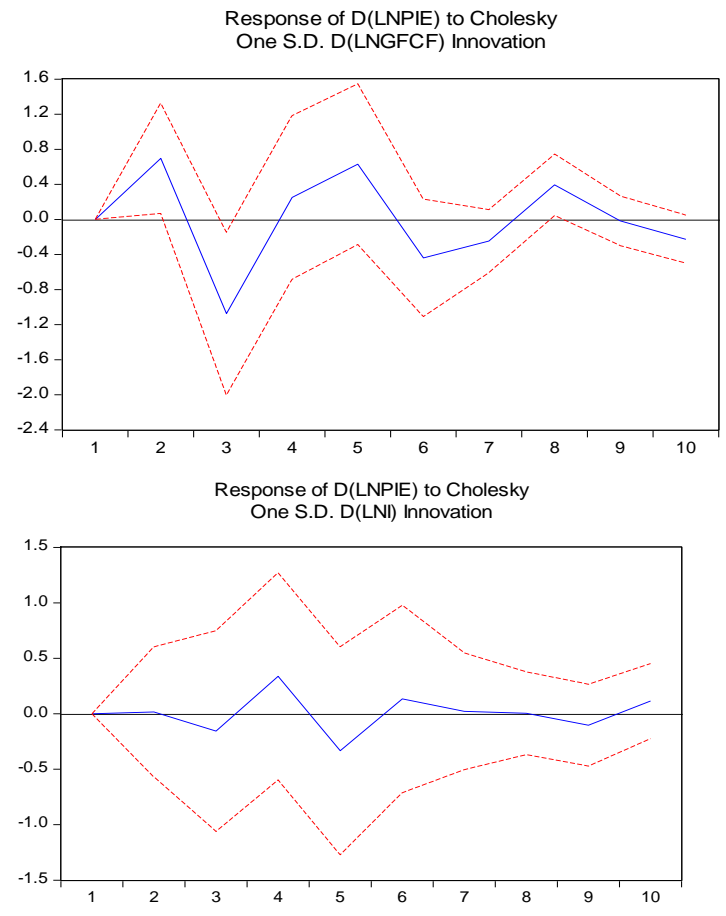

Response of D(LNPIE) to Cholesky One S.D. D(LNST) Innovation

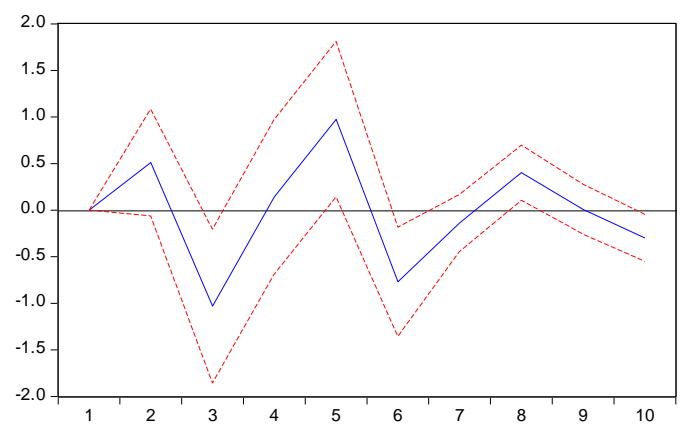



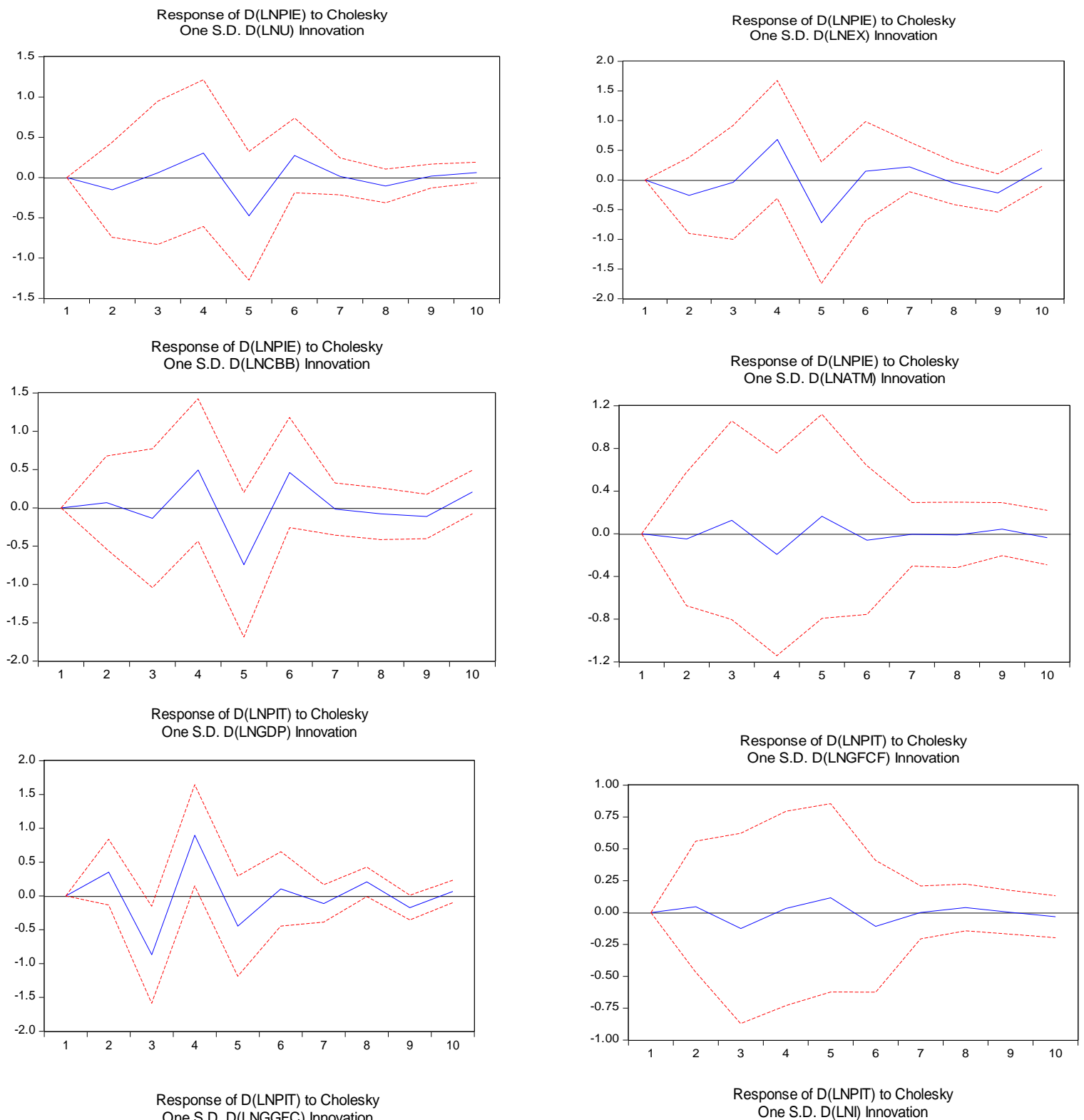

Response of D(LNPIT) to Cholesky One S.D. D(LNGGFC) Innovation
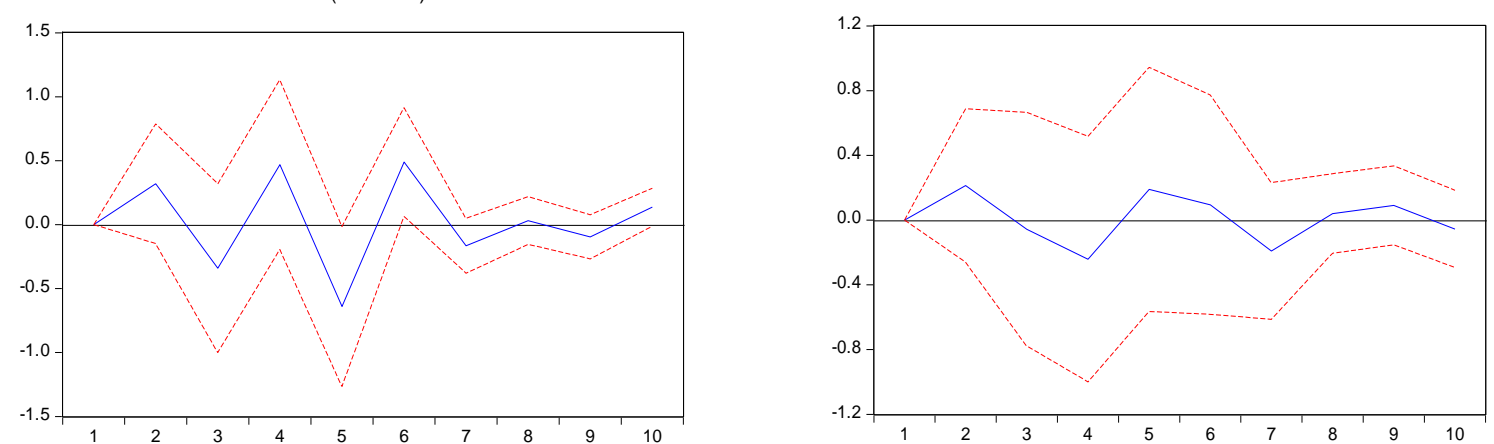

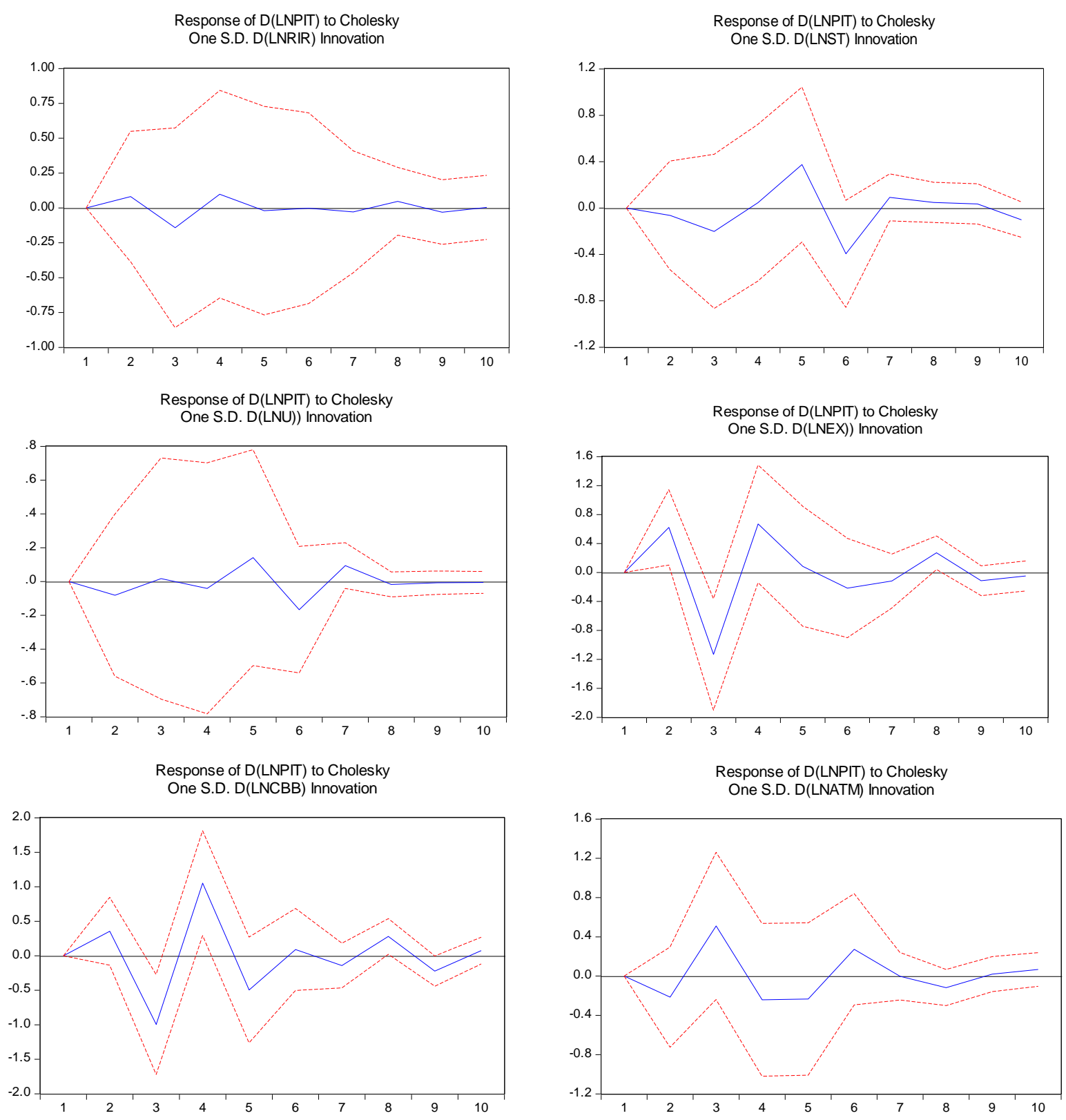

Figure 1. Impulse response analysis results

\section{Copyrights}

Copyright for this article is retained by the author(s), with first publication rights granted to the journal.

This is an open-access article distributed under the terms and conditions of the Creative Commons Attribution license (http://creativecommons.org/licenses/by/4.0/). 